\title{
Traumatic right coronary artery dissection
}

\author{
Mohamed A Ahmed, Samer Arnous
}

Cardiology Department University Hospital Limerick, Dooradoyle, Ireland

\section{Correspondence to} Dr Mohamed A Ahmed, Cardiology Department, James Cook University Hospital, Middlesbrough, United Kingdom; mod3llam@live.com

Accepted 28 December 2020

\section{DESCRIPTION}

A 61-year-old woman presented with two days history of intermittent left-sided chest pain, she is a smoker with a long history of poorly controlled high blood pressure. Clinical examination was remarkable for an ejection systolic murmur in the aortic area suggestive of aortic stenosis, ECG showed ST segment elevation in inferior leads.

She underwent an emergency coronary angiography that revealed a dissection of the proximal segment of the right coronary artery as well as a

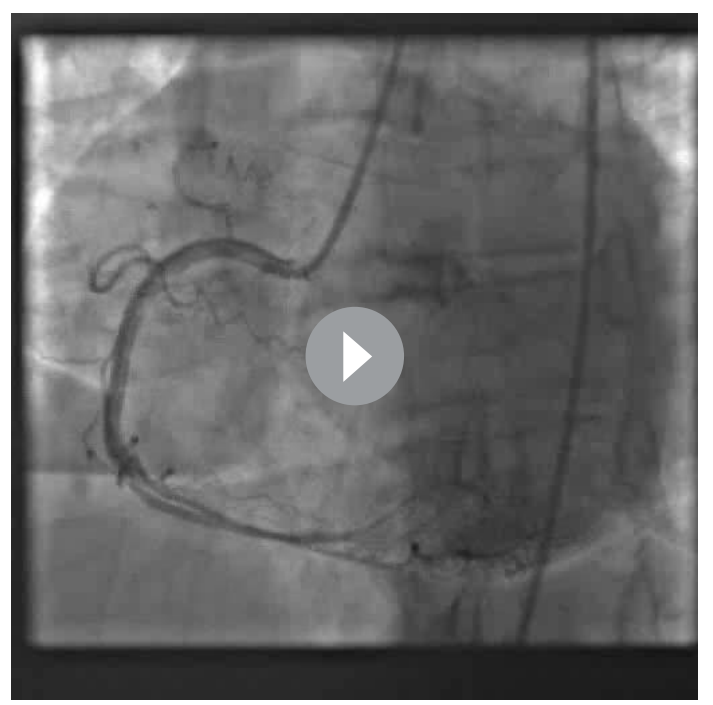

Video 1 Coronary angiography, left anterior oblique view of the right coronary artery showing a dissection flap extending from the ostium of the right coronary artery to the middle of the vessel with a large mobile mass noted on the aortic valve.

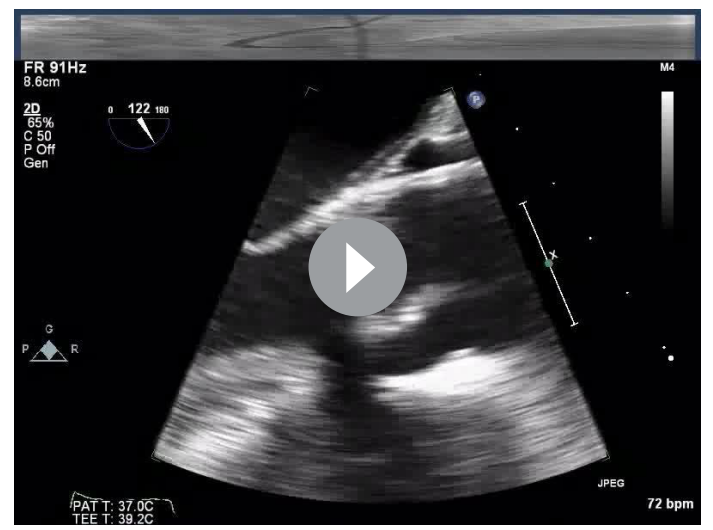

Video 2 Transoesophageal echocardiography showing a long axis view of the aortic valve in two dimension with heavy calcification of the aortic valve and a large mobile calcified mass on the right coronary cusp of the aortic valve.

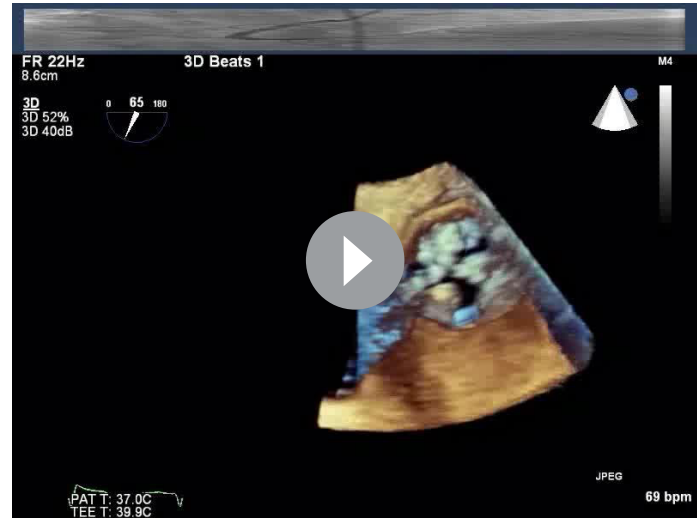

Video 3 Trans-oesophageal echocardiography showing a short axis view of the aortic valve in three dimension with a large mobile calcified mass on the right coronary cusp of the aortic valve.

mobile calcified mass originating from the right coronary cusp of the aortic valve (video 1 ). The dissection flap was covered with a drug eluting stent with an excellent final angiographic result.

Trans-thoracic echocardiography showed severe aortic valve stenosis with a large calcified mass on the right coronary cusp that was further evaluated with a trans-oesophageal echocardiogram (videos 2 and 3).

CT thoracic aorta showed no evidence of aortic root dissection or dilation and patient underwent aortic valve replacement 6 weeks later.

Coronary artery dissection is a rare entity that could be a primary spontaneous process or secondary to aortic root dissection and more frequently an iatrogenic complication of coronary artery intervention. ${ }^{1}$

In setting of aortic valve pathology, few cases of traumatic dissection were reported with clinical presentation of acute coronary syndrome. The suspected pathological mechanism is the detachment of calcified debris from the aortic valve resulting in acute obstruction of the coronary tree. Interestingly, one case report highlighted a

Learning points

- Coronary artery dissection is a rare cause of acute coronary syndrome.

- Aortic root pathology such as aortic root dissection should be ruled out in cases of coronary artery dissection.

- Importance of utilisation of different imaging modalities to evaluate aortic valve and aortic root pathology. 
potential association of spontaneous coronary artery dissection with bicuspid aortic valve. ${ }^{2}$

In our case, the potential aetiology of the right coronary artery dissection is secondary to 'the traumatic impact' of the large calcified aortic valve mass into the right coronary artery.

Contributors MAA: first author, collected images, organised data and wrote the manuscript. SA: second author, conducted the interpretation of the imaging and cowrote the manuscript.

Funding The authors have not declared a specific grant for this research from any funding agency in the public, commercial or not-for-profit sectors.
Competing interests None declared.

Patient consent for publication Obtained.

Provenance and peer review Not commissioned; externally peer reviewed.

\section{REFERENCES}

1 Vrints CJM. Spontaneous coronary artery dissection. Heart 2010;96:801-8.

2 Staico R, Armaganijan L, Lopes RD. Coronary embolism and calcified aortic valve: is there a correlation? J Thromb Thrombolysis 2012:34:425-7.

3 Labombarda F, Legallois D, Sabatier R. Spontaneous coronary artery dissection and bicuspid aortic valve. Arch Cardiovasc Dis 2009;102:857-8.

Copyright 2021 BMJ Publishing Group. All rights reserved. For permission to reuse any of this content visit

https://www.bmj.com/company/products-services/rights-and-licensing/permissions/

BMJ Case Report Fellows may re-use this article for personal use and teaching without any further permission.

Become a Fellow of BMJ Case Reports today and you can:

- Submit as many cases as you like

- Enjoy fast sympathetic peer review and rapid publication of accepted articles

- Access all the published articles

Re-use any of the published material for personal use and teaching without further permission

Customer Service

If you have any further queries about your subscription, please contact our customer services team on +44 (0) 2071111105 or via email at support@bmj.com.

Visit casereports.bmj.com for more articles like this and to become a Fellow 